\title{
Technical Efficiency Assessment of Intensive and Traditional Olive Farms in Southern Italy
}

Teodora Stillitano, Giacomo Falcone, Bruno Francesco Nicolò, Claudio Di Girolamo, Giovanni Gulisano, Anna Irene De Luca

Agraria Department, Mediterranea University of Reggio Calabria, Italy

\begin{abstract}
Olive-growing plays an important role in Southern Italy's agricultural sector. However, the profitability of many olive growing farms depends, still today, on public subsidies. The current changes in the European Common Agricultural Policy (CAP) 2014-2020, oriented towards the direct payments decreasing, will inevitably have important effects on farmer incomes. This is why the olive farms will have to increase their level of direct profitability to ensure their resilience on the market. Therefore, the measurement of technical efficiency plays a crucial role in identifying more efficient management practices, and for this aim, Data Envelopment Analysis (DEA) represents the most widely used technique in productivity analysis.

In this paper, constant returns to scale and variable returns to scale input-oriented models were used to investigate the technical and scale efficiency of intensive and traditional olive farms in Southern Italy, in order to highlight the performance of each farm.
\end{abstract}

Results showed technical inefficiencies in both olive systems and, suggesting that improvements in the input allocation among all farms are needed. Findings could be useful to suggest the adoption of management strategies to optimize the use of inputs, aiming to achieve suitable levels of productive performance.

\section{Keywords}

Olive-growing farms, scale efficiency, nonparametric analysis, Data Envelopment Analysis.

Stillitano, T., Falcone, G., Nicolò, B. F., Di Girolamo, C., Gulisano, G. and De Luca A. I. (2019) “Technical Efficiency Assessment of Intensive and Traditional Olive Farms in Southern Italy", AGRIS on-line Papers in Economics and Informatics, Vol. 11, No. 2, pp. 81-93. ISSN 1804-1930. DOI 10.7160/aol.2019.110208.

\section{Introduction}

According to FAOSTAT (2016), the worldwide cultivation of olive trees accounts more than 10.6 million of hectares, in respect to which Italy weights about $11 \%$, keeping itself the second most important producing country of olives, after Spain (with about 24\%). Olive growing plays a significant role in Italy's agricultural economy, indeed, in the national agricultural context, olive farms present high incidence, representing about $56 \%$ of the total number of Italian farms (ISTAT, 2010). In economic terms, the average value of Gross Saleable Production (GSP) of the olive farms amount to 1.7 million of euros, corresponding to about $3 \%$ of the national GSP of the agricultural sector. Relating to the southern Italian regions, this incidence grows to $10 \%$ (Scardera and Tosco, 2010); in particular olivegrowing is mainly widespread in Apulia, Calabria, and Sicily, which overall account for about $73 \%$ of the national olive oil production (ISTAT, 2016). Furthermore, it is noteworthy that olive-growing is able to provide a multifarious range of functions, besides the merely productive one, as for example ecosystem services, support for rural development, and guarantees of food safety (De Luca et al., 2018a, 2018b).

In Calabria region, olive cultivation systems are variegated, due to the co-existence of traditional and intensive orchards with low and high-density planting, respectively (Bernardi et al., 2018a; Stillitano et al., 2017, 2018). Traditional systems, that are mainly developed in hilly and mountainous areas, are characterized by low levels of adaptation, conversion, and mechanisation, often entailing a not economically viable crop management (Bernardi et al., 2016); on the contrary, the intensive systems are represented by higher yields (both of fruits and oil obtained), as well as higher levels of mechanization that result in high-quality 
olive oil production, and better levels of farm income (Giametta and Bernardi, 2010). Thus, in an increasingly competitive olive oil market, where the estimated global demand for extra virgin olive oil is steadily growing, modern intensive olive groves can represent an innovative and economically viable opportunity for farmers (Bernardi et al., 2018b; Sola-Guirado et al., 2018). Nevertheless, since the profitability of many Mediterranean olive farms depends, even now, on public subsidies, both reduction in direct payments and internal convergence processes implemented by Common Agricultural Policy (CAP) 2014-2020 reform will entail the decrease in direct support received by farmers, and consequently negative effect on their incomes. This is why the olive farms will have to increase their level of direct profitability to ensure their resilience on the market. In order to do so, a more efficient use of existing resources should be reached. In this context, technical efficiency of olive farms understood as the ability of an entrepreneur to maximize outputs given a certain combination of inputs or to minimize inputs given a certain level of outputs, need to increase. Data Envelopment Analysis (DEA), proposed by Charnes, Cooper, and Rhodes in 1978, has turned out to be the most widely used method in technical efficiency measurement. This paper deals with the analysis of technical, pure technical and scale efficiency of intensive and traditional olive farms in Calabria region (Southern Italy), in order to highlight their inefficiencies in the allocation of resources and thus identifying managerial improvement strategies which, if adopted by Calabrian farms, could represent a key element for their survival in the market.

\section{Theoretical background}

DEA is a non-parametric linear-programmingbased method developed by Charnes et al. (1978) and based on Farrell's (1957) efficiency definition. It represents the most widely used procedure in estimating the technical efficiency of decisionmaking units (DMUs), which convert multiple inputs into multiple outputs. As observed by Joro and Korhonen (2015), DMUs, which may include firms or parts of firms, must be comparable, i.e., they must perform essentially the same task using similar inputs to produce similar outputs, operating in similar environmental conditions. Technical efficiency consists in the ability of a DMU to maximize outputs given the same level of inputs and technology or to minimize inputs given a same level of outputs. In this sense, technical efficiency analysis can be oriented towards two different way: increasing output (output-oriented approach) or reducing input (input-oriented approach).

DEA allows the construction of a "best practice" frontier on which the efficient DMUs are located and that are used to measure the relative enefficiency of remaining inefficient units in terms of their distance from the frontier. For each inefficient DMU, DEA identifies the reference units or reference set by projecting it radially onto the efficient frontier. Thus, the reference set is used to benchmark these inefficiencies. When inefficient DMU is projected onto the frontier, its input/output are improved and, then, it can achieve its target values becoming efficient (Joro and Korhonen, 2015; Ozcan et al., 2014).

The most popular DEA approaches in scientific literature are the CCR (Charnes, Cooper, and Rhodes) model by Charnes et al. (1978) under the assumption of constant returns to scale (CRS) and, the BCC (Banker, Charnes, and Cooper) model by Banker et al. (1984) where variable returns to scale (VRS) are assumed. Constant returns to scale indicate that the firm is able to scale the inputs and outputs linearly without increasing or decreasing efficiency. Conversely, if a proportional increase in all the inputs results in a more than proportional increase in the single output, increasing returns to scale (IRS) occur; if it results in a less than proportional increase in the output, decreasing returns to scale (DRS) follow. The efficient DMUs are considered as having constant returns to scale.

The CRS model permits to estimate the overall technical efficiency (TE) of a DMU. TE efficiency, which takes no account of the scale effect, encompasses technical efficiency and scale efficiency. The former describes the efficiency in converting inputs to outputs; the latter identifies the productive scale size of a DMU and recognizes that economy of scale cannot be attained at all scales of production. The VRS model measures the pure technical efficiency (PTE) because it takes into account the variation of efficiency with respect to the scale of operation. The CRS/VRS ratio calculate the scale efficiency (SE). The CRS efficiency of a DMU is always less than or equal to the pure technical (VRS) efficiency. If a DMU is fully efficient in both the CCR and BCC scores, it is operating in the most productive scale size (Cooper et al., 2007; Ramanathan, 2003). A complete theoretical background of the DEA model can be found in Cooper et al. $(2006,2007,2011)$.

Technical efficiency in farming and the identification of its sources have received considerable attention by the scientific community as shown by Bravo- 
Ureta et al. (2007), who performed a meta-regression analysis including 167 technical efficiency studies at the firm level. Also, Liu et al. (2013) performed a literature survey on DEA applications, showing that agriculture and farm area was among the top-five industries addressed with a total number of papers equal to 258 from 1978 through August 2010. Recently, Emrouznejad and Yang (2018), who carried out a survey of the first 40 years of DEA-related articles in the literature from 1978 to 2016, revealed an exponential growth in the number of DEA applications since the seminal work of CCR in 1978. In this analysis, the agro-food sector was among the top 5 application fields of DEA with the greatest numbers of journal articles in 2015 and 2016.

Several researchers have used DEA for efficiency estimation in crop production. Among these, Banaeian et al. (2011) examined the technical and scale efficiency of Iranian greenhouse strawberry production by applying the inputoriented DEA technique. In another study by Mohammadi et al. (2011), the input-oriented DEA approach was employed to investigate the technical, pure technical and scale efficiency of kiwifruit production in Mazandaran province of Iran. Mousavi-Avval et al. (2012) used the DEA technique to evaluate the technical efficiency and identify the wasteful uses of the energy of barberry production in Iran. Mardani and Salarpour (2015) applied DEA to rank the technical efficiency of potato production in 23 Iranian provinces. Applications of DEA-Tobit two-step method have been found for rice farms: Dhungana et al. (2004) measured the economic inefficiency of Nepalese rice farms by employing the DEA technique to model efficiencies as an explicit function of discretionary variables, and a Tobit regression framework to explain variations in measured inefficiencies, while Boubacar et al. (2016) applied DEA models to estimate technical, pure technical and scale efficiency of rice farms in southwest of Niger, and Tobit regression to identify factors affecting their technical efficiency. With respect to the citrus cultivation, Beltrán-Esteve and Reig-Martínez (2014) compared the relative efficiency of organic and conventional citriculture systems in Spain in relation to a metafrontier that envelops both technologies and they analyzed the efficiency of each system through benchmarking process. Clemente et al. (2015) applied the output-oriented DEA approach in order to assess the technical efficiency of citrus producing properties in Brazil and he used an econometric approach to establish technical efficiency determinants. Focusing on the grape and wine sectors, Khoshroo et al. (2013) used a two-stage methodology, i.e. inputoriented DEA method and Tobit regression, to identify the inefficiencies and their sources in Iranian grape farmers. Vidal et al. (2013) examined the efficiency of Spanish Designations of origin (Dos) in the wine sector through a joint use of DEA and a new additive based measure known as "bounded adjusted measure". Urso et al. (2018) first investigated the comparative efficiency of wine and grapevine producers in Italy by using DEA model and, subsequently, they identified the determinants of the estimated levels of efficiency through an econometric model (Tobit). Applications of DEA can be found also for animal production sector, for example: Galanopoulos et al. (2006) used an input-oriented DEA model to evaluate the degree of technical and scale efficiency of commercial pig farming in Greece; Lansink and Reinhard (2004) applied DEA to compute input-based measures of technical efficiency of Dutch pig fattening farms; and Theodoridis et al. (2012) estimated the level of relative technical efficiency of Chios sheep farms in Greece by applied output-oriented DEA model.

In the field of olive production, several studies dealing with the computation of technical efficiency by employed DEA models. In the work by Amores and Contreras (2009), the DEA techniques were used to examine the economic efficiency of olive-growing farms in Andalusia and provide information for a better assignment of European agricultural subsidies. The results showed that the assignment of subsidies should be made in terms of Farm Efficiency results since the efficiency of farms would be under-estimated by an overall measurement (Overall Efficiency). Moreover, the results indicated that efficiency is positively related to the size of the farm and, then, large farms are more likely to improve their techniques. Artukoglu et al. (2010) compared the technical efficiency of organic and conventional olive farms in Turkey by using both input and output oriented DEA approaches. Their main finding was that the technical efficiency of conventional olive oil farms is lower than that of organic farms. Also, the Authors observed that the inefficiency is caused by the fact that the farms do not use minimum input or do not raise the maximum output from the actual inputs. In another study by Aparicio et al. (2016), a Luenberger-type indicator based on a specific weighted additive model in DEA was used to estimate and decompose productivity change for Protected Designations of Origin (PDOs) in the Spanish virgin olive oil sector. According to their results, the most productive PDOs were 
those with an important number of oil mills and packaging/marketing companies. Furthermore, their findings revealed that productivity changes were mostly the consequence of downwards and upwards of the frontier of the technology over time. The Authors suggested that these changes were explained, to a certain extent, by the evolution of the economic crisis. Jurado et al. (2017) employed the DEA method to analyze the level of economic efficiency of organic olive oil producers in Andalusia. In addition, a second DEA stage using quality comparative analysis was applied to obtained levels of efficiency. They found that only a very small number of organizations were efficient in terms of economic profitability. Moreover, the Authors observed that the commitment to online sales, the commitment to web tools, the academic training of the leading manager, exports and the size of the organization were clear determinants of the most efficient organizations.

\section{Materials and methods}

\section{Experimental design}

The data-set used in this study was collected from 40 olive farmers from the area of "Gioia Tauro Plain", located on the northern Tyrrhenian coast of Reggio Calabria province in Calabria (South Italy). This area was chosen as a representative of the Calabrian olive production, where olive growing cover $14.5 \%$ of the region's olive area $(185,915 \mathrm{ha})$, representing the most widespread agricultural activity (ISTAT, 2010). Local olivegrowing systems are mainly characterized by traditional and intensive orchards: the firsts developed mainly in hilly and mountainous areas with low-density planting (around 100 trees ha ${ }^{-1}$ ), while the second ones are based on moderate slope land and high-density planting (around 400 trees $\mathrm{ha}^{-1}$ ). Although most of these olive farms present limiting factors to quality of olive production, mainly due to low technological innovation degree in both olive cultivation and olive oil processing, the current tendency among local entrepreneurs is to adopt innovative and efficient management practices that could entail a more competitive position in the market. For sampling, a technique of non-probability sampling with reasoned choice and a stratified allocation was used. So, a sample of 40 olive farms was found and equally distributed between traditional and intensive olive growing systems (i.e., twenty farms for each cultivation system). For gathering the data, face-to-face survey method was conducted. The sample is mainly characterized by family farms with an average size from 4 to 13 ha, located in hilly areas. These farm units were chosen for their representativeness at the regional level.

\section{DEA model implementation}

This study aims at evaluating the performance of a farm by comparing it with the best managerial practices observed on the Pareto-efficient frontier. Specifically, with the purpose to evaluate the TE, PTE, and SE of olive farms examined, the inputoriented CRS and VRS models were applied. The choice to use both models was due to our interest in determining the returns to scale of the farms under study and estimating their scale efficiency. Furthermore, the choice of inputoriented approach finds its meaning in the limited inputs characterizing the agricultural sector (Toma et al., 2015), as well as in the major ability of producers to control inputs rather than output levels (Banaeian et al., 2011; Jiao et al., 2015). Therefore, it may be plausible to state that an inputoriented model is more appropriate to quantify the excess use of inputs during the production processes and to identify inputs optimization strategies also to support agriculturally sustainable pathways.

The following CRS DEA model (Cooper et al., 2011) was used to measure TE of olive farms under study:

$\min \theta-\varepsilon\left(\sum_{i=1}^{m} s_{i}^{-}+\sum_{r=1}^{s} s_{r}^{+}\right)$

subject to:

$$
\begin{aligned}
& \sum_{j=1}^{n} x_{i j} \lambda_{j}+s_{i}^{-}=\theta x_{i o} \quad i=1,2, \ldots, m ; \\
& \sum_{j=1}^{n} y_{r j} \lambda_{j}-s_{r}^{+}=y_{r o} \quad r=1,2, \ldots, s ; \\
& \lambda_{j}, s_{i}^{-}, s_{r}^{+} \geq 0 \forall i, j, r
\end{aligned}
$$

where $n$ is the number of DMUs to be evaluated; each DMU consumes $m$ inputs to produce s outputs; specifically, a DMUj consumes $x_{i j}$ of input $i$ and produces $y_{r j}$ of output $r ; \lambda_{j}$ are the weights assigned by the linear program; $s_{i}$ and $s_{r}$ are the input and output slacks (i.e., the additional improvement, decrease in inputs and/or increase in outputs, needed for a DMU to become efficient); $\varepsilon$ is a non-Archimedean element defined to be smaller than any positive real number. The value of $\theta$ obtained will determine the technical efficiency score of each DMU: if $\theta=1$, then DMU is efficient (frontier point); if $\theta<1 \mathrm{DMU}$ is inefficient and 
must decrease its inputs level. In order to determine PTE scores, a VRS DEA model is applied by adding the constraint $\sum_{j=1}^{n} \lambda_{j}=1$ to the equation (1).

Excel 2013 spreadsheet and DEA-Solver-LV were used for data processing. DEA program has been run separately for each olive system considered.

\section{Input and output description}

The input variables used in the efficiency analysis are the following: (1) total olive area (ha), (2) fixed capital costs $\left(€ \mathrm{ha}^{-1}\right)$, (3) variable capital costs $\left(€ \mathrm{ha}^{-1}\right)$ (4) human labour $\left(\mathrm{h} \mathrm{ha}^{-1}\right)$. As the output variable, gross saleable production ( $€$ ha-1) was selected. The total olive area included only owned land. Within the fixed capital costs, machinery and land investments ownership costs (i.e. depreciations, insurance, repairs, and maintenance) were included. Variable capital costs (i.e. fertilizers, pesticides, herbicides, and fuel and oil consumption used in the olive production process) were calculated according to the market pricing referred to 2016. Family labour needed during agricultural operations was measured in terms of opportunity cost and was equalized to the employment of casual workers (Stillitano et al., 2016, 2017). Finally, the gross saleable production was evaluated by multiplying the average olive production by its market price referred to the last harvesting season (2015-2016) and by excluding EU Agricultural Policy subsidies. The olive average selling price was provided by the Istituto di Servizi per il Mercato Agricolo Alimentare (ISMEA) and referred to the 2015/2016 harvesting season. To evaluate farm efficiency excluding subsidy contribution, no subsidy was added in farm gross saleable production.
Subsequently, the amounts of subsidy were added to estimate the impact on farm efficiency. The variables (inputs and outputs) selected in this study were in line with those utilized in similar studies already mentioned in the introduction section.

Descriptive statistics for inputs and outputs used in each olive system under study are displayed in Table 1. It is worth noting the low variability in the size of all the variables because of the homogeneous features of the sample.

\section{Results and discussion}

In Table 2 the results achieved by the implementation of input-oriented CCR and BCC DEA models are reported. The findings revealed that average technical efficiency (TE score), under CRS assumption and excluding EU subsidies, of intensive olive farms $(0.760)$ was greater than of traditional ones (0.728). This means that, on average, the farms could reduce their inputs, and, then, reducing production costs, by $24 \%$ and $27.2 \%$, respectively, providing the same level of production. According to Mohammadi et al. (2011), the variation in the technical efficiency of farmers could be caused by the incorrect application of the appropriate production techniques.

Under VRS assumption and excluding subsidies, the traditional farms had higher PTE score (0.992) compared to intensive farms (0.989), although there are no significant differences. It is worth noting the greater pure technical efficiency than overall technical efficiency in both farm systems. This is highlighted by a low level of average

\begin{tabular}{|c|c|c|c|c|c|c|}
\hline \multicolumn{7}{|c|}{ Intensive Farms } \\
\hline & \multirow{2}{*}{$\begin{array}{l}\text { Olive area } \\
\text { harvested }\end{array}$} & \multirow{2}{*}{$\begin{array}{l}\text { Fixed capital } \\
\text { costs }\end{array}$} & \multirow{2}{*}{$\begin{array}{c}\text { Variable } \\
\text { capital costs }\end{array}$} & \multirow[b]{2}{*}{ Human labour } & \multicolumn{2}{|c|}{ Gross Saleable Production } \\
\hline & & & & & $\begin{array}{l}\text { Without } \\
\text { subsidies }\end{array}$ & $\begin{array}{c}\text { With } \\
\text { subsidies }\end{array}$ \\
\hline & (ha) & $\left(€ \mathrm{ha}^{-1}\right)$ & $\left(€\right.$ ha $\left.^{-1}\right)$ & $\left(\mathrm{h} \mathrm{ha}^{-1}\right)$ & \multicolumn{2}{|c|}{$\left(€\right.$ ha $\left.^{-1}\right)$} \\
\hline Max & 15 & $2,073.10$ & $1,994.30$ & 146.50 & $9,900.00$ & $11,800.00$ \\
\hline Min & 5 & 809.20 & $1,043.80$ & 102.50 & $4,320.00$ & $6,220.00$ \\
\hline Average & 8.8 & $1,334.16$ & $1,387.33$ & 113.36 & $6,568.00$ & $8,468.00$ \\
\hline St Dev & 2.32 & 324.54 & 248.58 & 9.44 & $1,592.04$ & $1,592.04$ \\
\hline \multicolumn{7}{|c|}{ Traditional Farms } \\
\hline Max & 13 & $3,208.54$ & $1,862.96$ & 264.50 & $4,940.00$ & $6,840.00$ \\
\hline Min & 4 & $1,131.73$ & $1,097.50$ & 235.50 & $2,040.00$ & $3,940.00$ \\
\hline Average & 7.75 & $1,882.38$ & $1,344.18$ & 257.18 & $3,018.80$ & $4,931.30$ \\
\hline St Dev & 2.26 & 588.74 & 246.79 & 9.12 & 731.31 & 724.16 \\
\hline
\end{tabular}

Source: own processing 


\begin{tabular}{|c|c|c|c|c|c|c|c|}
\hline \multirow{3}{*}{ DMU } & \multicolumn{7}{|c|}{ Intensive Farms } \\
\hline & TE score & PTE score & SE score & TE score & PTE score & SE score & \multirow{2}{*}{ RTS } \\
\hline & \multicolumn{3}{|c|}{ Without subsidies } & \multicolumn{3}{|c|}{ With subsidies } & \\
\hline 1 & 0.6493 & 0.9896 & 0.6561 & 0.7291 & 0.9896 & 0.7368 & IRS \\
\hline 2 & 0.7209 & 1 & 0.7209 & 0.7772 & 1 & 0.7772 & IRS \\
\hline 3 & 0.7067 & 0.9876 & 0.7156 & 0.7636 & 0.9876 & 0.7732 & IRS \\
\hline 4 & 0.7332 & 1 & 0.7332 & 0.7955 & 1 & 0.7955 & IRS \\
\hline 5 & 0.725 & 0.9888 & 0.7332 & 0.7834 & 0.9888 & 0.7923 & IRS \\
\hline 6 & 0.8314 & 0.9757 & 0.8521 & 0.867 & 0.9757 & 0.8886 & IRS \\
\hline 7 & 0.9315 & 1 & 0.9315 & 0.9502 & 1 & 0.9502 & IRS \\
\hline 8 & 0.7049 & 1 & 0.7049 & 0.7768 & 1 & 0.7768 & IRS \\
\hline 9 & 0.8163 & 1 & 0.8163 & 0.8855 & 1 & 0.8855 & IRS \\
\hline 10 & 1 & 1 & 1 & 1 & 1 & 1 & CRS \\
\hline 11 & 0.5788 & 0.9856 & 0.5873 & 0.675 & 0.9856 & 0.6849 & IRS \\
\hline 12 & 0.6926 & 1 & 0.6926 & 0.8019 & 1 & 0.8019 & IRS \\
\hline 13 & 0.5844 & 0.9317 & 0.6272 & 0.6553 & 0.9317 & 0.7033 & IRS \\
\hline 14 & 0.7481 & 1 & 0.7481 & 0.8934 & 1 & 0.8934 & IRS \\
\hline 15 & 1 & 1 & 1 & 1 & 1 & 1 & CRS \\
\hline 16 & 1 & 1 & 1 & 1 & 1 & 1 & CRS \\
\hline 17 & 0.6349 & 0.973 & 0.6525 & 0.6981 & 0.973 & 0.7175 & IRS \\
\hline 18 & 0.6548 & 0.9565 & 0.6846 & 0.7065 & 0.9565 & 0.7386 & IRS \\
\hline 19 & 0.8312 & 1 & 0.8312 & 0.9623 & 1 & 0.9623 & IRS \\
\hline 20 & 0.6604 & 1 & 0.6604 & 0.7352 & 1 & 0.7352 & IRS \\
\hline Average & 0.76 & 0.989 & 0.767 & 0.823 & 0.989 & 0.831 & \\
\hline $\operatorname{Max}$ & 1 & 1 & 1 & 1 & 1 & 1 & \\
\hline Min & 0.579 & 0.932 & 0.587 & 0.655 & 0.932 & 0.685 & \\
\hline St Dev & 0.134 & 0.018 & 0.129 & 0.114 & 0.018 & 0.107 & \\
\hline \multirow{3}{*}{$\mathrm{DMU}$} & \multicolumn{7}{|c|}{ Traditional Farms } \\
\hline & TE score & PTE score & SE score & TE score & PTE score & SE score & \multirow{2}{*}{ RTS } \\
\hline & \multicolumn{3}{|c|}{ Without subsidies } & \multicolumn{3}{|c|}{ With subsidies } & \\
\hline 1 & 0.6245 & 0.9844 & 0.6344 & 0.7432 & 0.9844 & 0.755 & IRS \\
\hline 2 & 0.7266 & 0.9896 & 0.7342 & 0.817 & 0.9896 & 0.826 & IRS \\
\hline 3 & 0.8361 & 1 & 0.8361 & 0.8979 & 1 & 0.898 & IRS \\
\hline 4 & 1 & 1 & 1 & 1 & 1 & 1 & CRS \\
\hline 5 & 0.854 & 1 & 0.854 & 0.9181 & 1 & 0.918 & IRS \\
\hline 6 & 0.6976 & 1 & 0.6976 & 0.8043 & 1 & 0.804 & IRS \\
\hline 7 & 0.8724 & 0.9993 & 0.873 & 0.9275 & 0.9993 & 0.928 & IRS \\
\hline 8 & 0.8513 & 0.9936 & 0.8568 & 0.8975 & 0.9936 & 0.903 & IRS \\
\hline 9 & 0.6165 & 1 & 0.6165 & 0.7586 & 1 & 0.759 & IRS \\
\hline 10 & 1 & 1 & 1 & 1 & 1 & 1 & CRS \\
\hline 11 & 0.583 & 1 & 0.583 & 0.7544 & 1 & 0.754 & IRS \\
\hline 12 & 0.4818 & 0.9403 & 0.5124 & 0.6257 & 0.9403 & 0.665 & IRS \\
\hline 13 & 0.6559 & 1 & 0.6559 & 0.9123 & 1 & 0.912 & IRS \\
\hline 14 & 0.7351 & 0.9774 & 0.7521 & 0.847 & 0.9774 & 0.867 & IRS \\
\hline 15 & 0.5352 & 0.9938 & 0.5385 & 0.6725 & 0.9938 & 0.677 & IRS \\
\hline 16 & 1 & 1 & 1 & 1 & 1 & 1 & CRS \\
\hline 17 & 0.682 & 0.9796 & 0.6962 & 0.7723 & 0.9796 & 0.788 & IRS \\
\hline 18 & 0.4951 & 0.9818 & 0.5043 & 0.6551 & 0.9818 & 0.667 & IRS \\
\hline 19 & 0.6878 & 1 & 0.6878 & 0.8268 & 1 & 0.827 & IRS \\
\hline 20 & 0.6194 & 1 & 0.6194 & 0.864 & 1 & 0.864 & IRS \\
\hline Average & 0.728 & 0.992 & 0.733 & 0.835 & 0.992 & 0.841 & \\
\hline Max & 1 & 1 & 1 & 1 & 1 & 1 & \\
\hline Min & 0.482 & 0.94 & 0.504 & 0.626 & 0.94 & 0.665 & \\
\hline St Dev & 0.163 & 0.015 & 0.159 & 0.113 & 0.015 & 0.104 & \\
\hline
\end{tabular}

Source: own processing

Table 2: DEA scores and returns to scale for the farms under study. 
scale efficiency which was far to the optimal size, with a value of approximately 0.733 and 0.767 in traditional and intensive systems, respectively. This results in a production scale that is not generally optimal in olive cultivation, as observed by Idda et al. (2004) who investigated technical and economic efficiency of Sardinian olive farms (Italy) by applied DEA technique. Also, Mousavi-Avval et al. (2012) confirm that the high difference between TE and PTE scores designates disadvantageous conditions of scale size.

The outcomes achieved so far, can be better explained by analyzing the efficiency score distribution as illustrated in Fig. 1 and 2 . By applying the CRS model (excluding subsidies), the most of the intensive olive farms, equal to $55 \%$ of total, had technical efficiency between 0.60 and $0.79 ; 10 \%$ had technical efficiency of less than 0.60 and $20 \%$ of farms were close to the DEA frontier, showing technical efficiency score between 0.80 and 0.99 . Only $15 \%$ of farms were full technical efficient, indicating rational management of existing technology and no improvement on input use. When the VRS model is carried out, $60 \%$ of the intensive farms exhibited the full efficiency score and no farm operated below 0.80 of the efficiency level. This wide variation between
TE and PTE score confirms that the majority of farms in the samples don't achieve the optimal scale size. Also analyzing the Return to Scale (RTS) it occurs that 17 intensive farms operated under increasing returns to scale and only three exhibited constant returns to scale (see Table 2). These findings suggest that small farm size of the olive farms under study leads to a failure to achieve an optimal production scale.

As to the traditional olive farms, under CRS assumption the analysis showed that $15 \%$ of farmers had a technical efficiency of unity; $20 \%$ operated between 0.80 and 0.99 of the efficiency level and $65 \%$ below 0.80 . Under the VRS model, $55 \%$ of traditional farms exhibited a pure technical efficiency score of one and the remaining farms $(45 \%)$ had a score between 0.80 and 0.99 . The return to scale analysis revealed that only three DMUs operated at the most productive scale size under CRS model and showing scale efficiency of one. The remaining farms revealed increasing returns to scale, indicating that technological change are necessary for changes in yield, as debated by Banaeian et al. (2011), as well as the need to increase their size in order to reach cost savings, as argued by Jiao et al. (2015).
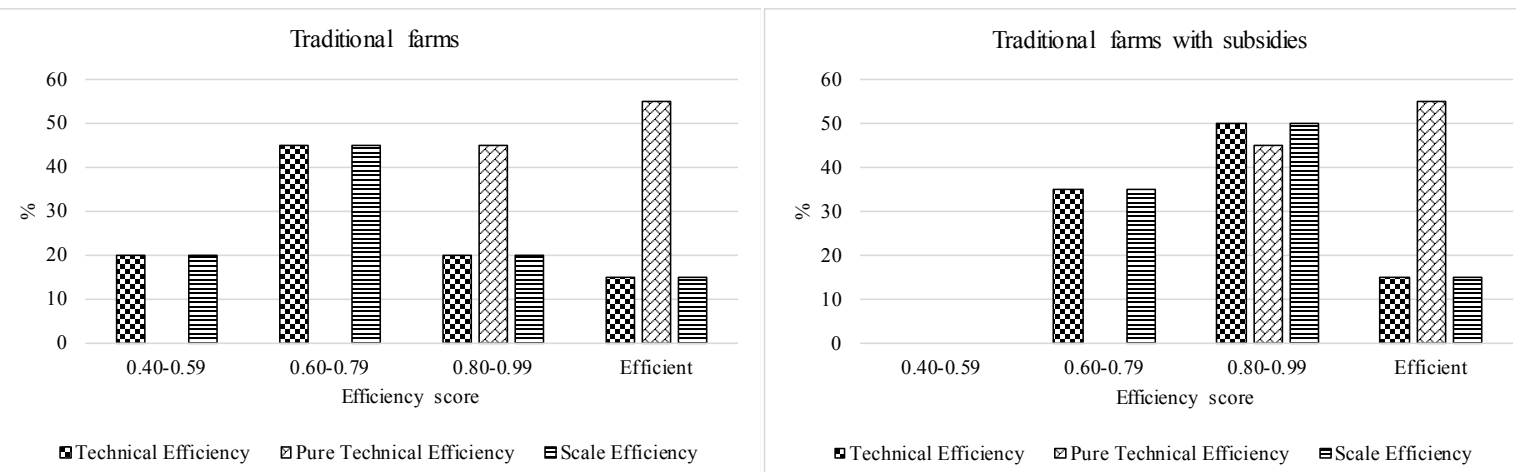

Source: own processing

Figure 1: Efficiency score distribution for the traditional farms under study
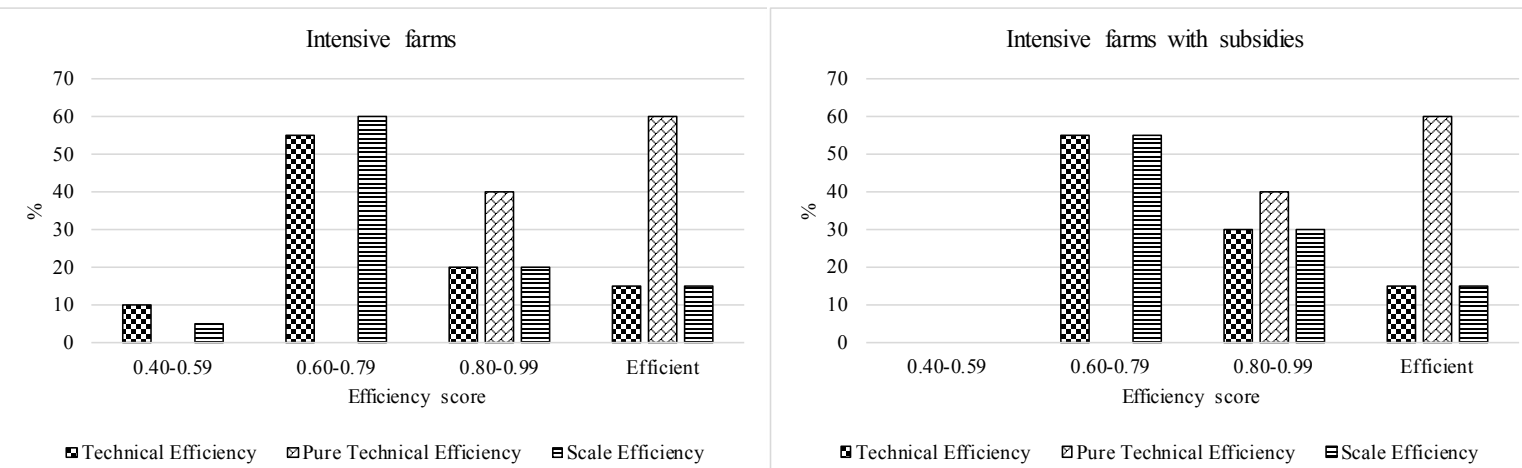

Source: own processing

Figure 2: Efficiency score distribution for the intensive farms under study. 
When EU subsidies are included in the output, improvements in terms of overall technical efficiency and scale efficiency are identified. For intensive farms, the average TE score (0.823) and SE score (0.831) were higher than that obtained by excluding subsidies $(0.760$ and 0.767 , respectively). In terms of efficiency score distribution, an increase in farms' number of the 0.80 and 0.99 range was achieved. Also for traditional farmers, a higher TE score $(0.835 \mathrm{vs}$. 0.728 ) and SE score (0.841 vs. 0.733$)$ were found. However, the addition of subsidies did not affect the farms' percentage which reaches the all-out efficiency, endorsing the results obtained by Oxouzi et al. (2012). As debated by Galanopoulos et al. (2006), DEA model provides valuable information about managerial evaluation of all technically inefficient DMUs, allowing to identify and compute the sources of inefficiency. This is in turn enables a DMU to achieve the potential improvement of their productive performance. As an example, in Table 3 the evaluation of the efficient input use levels of two inefficient DMU, i.e. DMU17 for intensive farms and DMU18 for traditional ones, is reported. The technical efficiency (TE) of DMU17 was found to be 0.635 suggesting that a $36.5 \%$ decrease of its inputs is possible without decreasing the level of gross saleable production. Thus, by reducing its actual input (second row of Table 3) DMU17 is projected radially onto the best practice frontier. As this olive farm still cannot reach the efficiency frontier, slack adjustments are needed to push the DMU to the frontier (Ozcan, 2014). By adding these further input reductions and, especially, reducing variable capital costs and human labour by another $9.2 \%$ and $5.9 \%$, respectively, DMU17 reach its efficiency target (at frontier) becoming Pareto-efficient (fifth row of Table 3).

DMU18 with a TE score of 0.495 could reduce its input levels proportionally by $50.5 \%$, providing actual production level. For this olive farm, only slack adjustments in human labour (-13.58 $\left.\mathrm{h} \mathrm{ha}^{-1}\right)$ are needed in order to become a Pareto optimal point.

As reported by Joro and Korhonen (2015), DEA is a benchmarking technique since inefficient DMUs are benchmarked against the efficient frontier. For each inefficient unit, efficiency analysis in DEA identify the corresponding peers, named reference set or peer group, within the efficient existing units. If an inefficient DMU corresponds more than one peer, then it is necessary to identify for each peer its contribution (i.e., peer weight or lambda) to the computation of score (Cooper et al., 2011). In Table 4, for the inefficient DMUs 18 and 12, the corresponding peer group, as well as efficiency targets for inputs, are identified. For DMU18 the peers and their corresponding weights were $2(0.31), 10(0.063)$ and $16(0.628)$. By multiplying the lambda value by the input level of the respective efficient DMU, the input targets were calculated. The results revealed that the most influential benchmark was DMU16, representing the $62.8 \%$ of the ideal peer for DMU18. For DMU12, the benchmark DMUs were 10(0.7), 11(0.242) and $13(0.058)$. It can be seen that DMU10 was the best reference unit, with $70 \%$ of the ideal peer. As argued by Hosseinzadeh-Bandbafha et al. (2018), the benchmarking approach allows inefficient farms

\begin{tabular}{lcccc}
\hline \multicolumn{4}{c}{ Intensive Farms } \\
\hline & $\begin{array}{c}\text { Olive area } \\
\text { harvested }\end{array}$ & $\begin{array}{c}\text { Fixed capital } \\
\text { costs }\end{array}$ & $\begin{array}{c}\text { Variable } \\
\text { capital costs }\end{array}$ & Human labour \\
\cline { 2 - 5 } & $($ ha $)$ & $\left(€\right.$ ha $\left.^{-1}\right)$ & $\left(€\right.$ ha $\left.^{-1}\right)$ & $\left(\mathrm{h} \mathrm{ha}^{-1}\right)$ \\
\hline Actual values & 9.00 & $1,206.60$ & $1,525.73$ & 111.00 \\
Radial movement & -3.29 & -440.53 & -557.05 & -40.53 \\
Projected point & 5.71 & 766.07 & 968.69 & 70.47 \\
Slack adjustment & 0.00 & 0.00 & -140.56 & -6.58 \\
Pareto-efficient point & 5.71 & 766.07 & 828.13 & 63.89 \\
\hline & & Traditional Farms & & \\
\hline DMU18 & & & $1,516.53$ & 255.50 \\
\hline Actual values & 9.00 & $1,510.07$ & -765.70 & -129.00 \\
Radial movement & -4.54 & -762.44 & 750.84 & 126.50 \\
Projected point & 4.46 & 747.64 & 0.00 & -13.58 \\
Slack adjustment & 0.00 & 0.00 & 750.84 & 112.91 \\
Pareto-efficient point & 4.46 & 747.64 & & \\
\hline
\end{tabular}

Source: own processing

Table 3: Actual and efficient input use levels of DMU17 and DMU18. 


\begin{tabular}{|c|c|c|c|c|c|}
\hline & \multicolumn{5}{|c|}{ Intensive Farms } \\
\hline & \multirow{2}{*}{ DMU18 } & \multicolumn{3}{|c|}{ Input use levels of peers } & \multirow{2}{*}{ Input Targets } \\
\hline & & DMU2 & DMU10 & DMU16 & \\
\hline Lambda & & 0.31 & 0.063 & 0.628 & \\
\hline \multicolumn{6}{|l|}{ Input } \\
\hline Olive area harvested & 10 & 9 & 8 & 10 & 9.57 \\
\hline Fixed capital costs & $1,223.588$ & $1,136.23$ & $1,306.19$ & $1,173.70$ & $1,171.61$ \\
\hline Variable capital costs & $1,994.30$ & $1,230.63$ & $1,369.60$ & $1,299.10$ & $1,283.62$ \\
\hline Human labour & 109.1 & 108.5 & 102.5 & 102.5 & 104.46 \\
\hline \multicolumn{6}{|l|}{ Output } \\
\hline \multirow[t]{4}{*}{ GPV } & $6,600.00$ & $6,600.00$ & $92,40.00$ & $9,900.00$ & $6,600.00$ \\
\hline & \multicolumn{5}{|c|}{ Traditional Farms } \\
\hline & \multirow{2}{*}{ DMU12 } & \multicolumn{3}{|c|}{ Input use levels of peers } & \multirow{2}{*}{ Input Targets } \\
\hline & & DMU10 & DMU11 & DMU13 & \\
\hline Lambda & & 0.7 & 0.242 & 0.058 & \\
\hline \multicolumn{6}{|l|}{ Input } \\
\hline Olive area harvested & 6 & 6 & 5 & 4 & 5.64 \\
\hline Fixed capital costs & $2,442.06$ & $2,102.64$ & $2,638.45$ & $3,208.54$ & $2,296.45$ \\
\hline Variable capital costs & $1,530.90$ & $1,239.40$ & $1,640.20$ & $1,553.50$ & $1,354.61$ \\
\hline Human labour & 260 & 237.5 & 261 & 260 & 244.49 \\
\hline \multicolumn{6}{|l|}{ Output } \\
\hline GPV & $2,380.00$ & $4,940.00$ & $2,400.00$ & $2,160.00$ & $2,380.00$ \\
\hline
\end{tabular}

Source: own processing

Table 4: Input Targets of DMU18 and DMU12 referred to their peers (based on BCC model).

to identify the reasons for inefficiency and find the best practices for improving production processes.

As mentioned before, several studies in scientific literature dealing with the efficiency assessment of olive farming, but most of these do not compare traditional and intensive olive-growing systems. The only ones to do it are GómezLimón et al. (2012) that use a different empirical (and then not comparable with the present) DEA approach and pressure distance functions to assess the eco-efficiency of Andalusian traditional and irrigated intensive groves, and Niavis et al. (2018), which assess technical efficiency levels of extensive olive tree cultivation in Greek by implementing DEA input-oriented model, but without extend the sample to intensive systems.

\section{Conclusion}

This paper based on a sample survey of local farms assessed the technical efficiency of intensive and traditional olive farms in Southern Italy by employing input-oriented CRS and VRS models. The findings showed that intensive farms achieve a greater technical efficiency, under CRS assumption and excluding EU subsidies than traditional ones, while under VRS assumption their efficiency is lower, although no significant differences have emerged. However, technical inefficiencies among all farms, regarding the use of inputs, were found and, likely caused by the incorrect application of the appropriate production techniques. The variable capital costs and the use of human labour, especially in traditional farms, were the worst managed input in the sample examined. Thus, these inefficiencies need to be correct in order to increase farms' performance and, therefore, their profitability. A higher level of technical efficiency through a potential reduction in input use would bring a decrease of average production cost and improve the competitiveness of farms.

The results also showed the greater pure technical efficiency than overall technical efficiency in both farm systems, suggesting disadvantageous conditions of scale size. This wide variation between TE and PTE score endorse that the majority of farms in the samples don't achieve the optimal scale size. Likewise, return to scale analysis revealed that only a very small number of farms may be considered full efficient, while the remaining ones operated under increasing returns to scale, suggesting that small farm size 
leads to a failure to achieve an optimal production scale. When EU subsidies were included in the analysis, findings highlighted improvements in terms of overall technical efficiency and scale efficiency, though this did not affect the farms' percentage which reaches the all-out efficiency.

The choice to use an input-oriented DEA model was due to the great potential of this approach to provide useful information about the excess use of inputs during the production processes. A better understanding of the resource use can offer evidence supporting inputs optimization strategies not only for cost savings but also for contributing to a more sustainable olive production. Although this study is the first step to a more extensive research work in which a more structured model will be implemented, it can contribute to expanding the knowledge of olive growing contexts in terms of production efficiency. However, some limitations of the research need to be furtherly investigated in order to guarantee a more adequate assessment of the farm's efficiency. Two concerns, in particular, are those to extend the data sample and justifying the efficiencies differences in the input use.

Corresponding authors

Anna Irene De Luca,

Agraria Department, Mediterranea University of Reggio Calabria

Feo di Vito, 89122 Reggio Calabria, Italy

Email: anna.deluca@unirc.it

\section{References}

[1] Amores, A. F. and Contreras, I. (2009) "New approach for the assignment of new European agricultural subsidies using scores from data envelopment analysis: Application to olive-growing farms in Andalusia (Spain)", European Journal of Operational Research, Vol. 193, No. 3, pp. 718-729. ISSN 0377-2217. DOI 10.1016/j.ejor.2007.06.059.

[2] Aparicio, J., Monge, J. F., Ortiz, L. and Pasto, J. T. (2016) "Changes in productivity in the virgin olive oil sector: An application to protected designations of origin in Spain", Spanish Journal of Agricultural Research, Vol. 14, No. 3, 12 p. ISSN 2171-9292. DOI 10.5424/sjar/2016143-9433.

[3] Artukoglu, M. M., Olgun, A. and Adanacioglu, H. (2010) "The efficiency analysis of organic and conventional olive farms: Case of Turkey”, Agricultural Economics, Vol. 56, No. 2, pp. 89-96. ISSN 0139-570X.

[4] Banaeian, N., Omid, M. and Ahmadi, H. (2011) "Application of Data Envelopment Analysis to Evaluate Efficiency of Commercial Greenhouse Strawberry", Research Journal of Applied Sciences, Engineering and Technology, Vol. 3, No. 3, pp. 185-193. ISSN 2040-7467.

[5] Banker, R. D., Charnes, A. and Cooper, W. W. (1984) "Some models for estimating technical and scale inefficiencies in Data Envelopment Analysis”, Management Science, Vol. 30, No. 9, pp. 1078-1092. ISSN 0025-1909. DOI 10.1287/mnsc.30.9.1078.

[6] Beltrán-Esteve, M. and Reig-Martínez, E. (2014) "Comparing conventional and organic citrus grower efficiency in Spain”, Agricultural Systems, Vol. 129, pp. 115-123. ISSN 0308-521X. DOI 10.1016/j.agsy.2014.05.014.

[7] Bernardi, B., Benalia, S., Fazari, A., Zimbalatti, G., Stillitano, T. and De Luca, A. I. (2016) "Mechanical harvesting in traditional olive orchards: Oli-picker case study", Agronomy Research, Vol. 14, No. 3, pp. 683-688. ISSN 1406-894X.

[8] Bernardi, B., Falcone, G., Stillitano, T., Benalia, S., Strano, A., Bacenetti, J. and De Luca, A. I. (2018a) "Harvesting system sustainability in Mediterranean olive cultivation", Science of the Total Environment, Vol. 625, pp. 1446-1458. ISSN 0048-9697. DOI 10.1016/j.scitotenv.2018.01.005. .

[9] Bernardi, B., Castro-García, S., Blanco-Roldán, G. L., Benalia, S., Fazari, A. and Zimbalatti, G. (2018b) "A comparison between two materials for head-clamping pads of olive tree shakers: First trials", Acta Horticulturae, Vol. 1199, pp. 403-408. ISSN 2406-6168. DOI 10.17660/ActaHortic.2018.1199.64. 
[10] Boubacar, O., Hui-qiu, Z., Rana, M. A. and Ghazanfar, S. (2016) "Analysis on Technical Efficiency of Rice Farms and Its Influencing Factors in South-western of Niger", Journal of Northeast Agricultural University, Vol. 23, No. 4, pp. 67-77. ISSN 1006-8104. DOI 10.1016/S1006-8104(17)30009-0.

[11] Bravo-Ureta, B., Solís, D., Moreira-López, V., Maripani, J., Thiam, A. and Rivas, T. (2007) "Technical efficiency in farming: a meta-regression analysis", Journal of Productivity Analysis, Vol. 27, pp. 57-72. ISSN 0895-562X. DOI 10.1007/s11123-006-0025-3.

[12] Charnes, A., Cooper, W. W. and Rhodes, E. (1978) "Measuring the efficiency of decision-making units", European Journal of Operational Research, Vol. 2, No. 6, pp. 429-444. ISSN 0377-2217. DOI 10.1016/0377-2217(78)90138-8.

[13] Clemente, F., Lírio, V.S. and Gomes, M. F. M. (2015): "Technical efficiency in Brazilian citrus production", Bio-based and Applied Economics, Vol. 4, No. 2, pp. 165-178. ISSN 2280-6180. DOI 10.13128/BAE-13597.

[14] Cooper, W. W., Seiford, L. and Tone, K. (2007) "Data Envelopment Analysis: A Comprehensive Text with Models, Applications, References and DEA-Solver Software", $2^{\text {nd }}$ ed., New York, Springer US, 490 p. ISBN 978-0-387-45283-8.

[15] Cooper, W. W., Seiford, L. and Tone, K. (2006) "Introduction to Data Envelopment Analysis and Its Uses", New York, Springer US, 354 p. ISBN 978-0-387-29122-2.

[16] Cooper, W. W., Seiford, L. and Zhu, J. (2011) "Handbook on Data Envelopment Analysis", $2^{\text {nd }}$ ed., New York, Springer US, 498 p. ISBN 978-1-4419-6151-8.

[17] De Luca, A. I., Iofrida, N., Falcone, G., Stillitano, T. and Gulisano, G. (2018a) "Olive growing scenarios of soil management: Integrating environmental, economic and social indicators rom a life-cycle perspective", Acta Horticulturae, Vol. 1199, pp. 209-214. ISSN 2406-6168. DOI 10.17660/ActaHortic.2018.1199.34.

[18] De Luca, A. I., Falcone, G., Stillitano, T., Iofrida, N., Strano, A. and Gulisano, G. (2018b) “Evaluation of sustainable innovations in olive growing systems: A Life Cycle Sustainability Assessment case study in southern Italy", Journal of Cleaner Production, Vol. 171, pp. 1187-1202. ISSN 0959-6526. DOI 10.1016/j.jclepro.2017.10.119.

[19] Dhungana, B. R., Nuthall, P. L. and Nartea, G. V. (2004) "Measuring the economic inefficiency of Nepalese rice farms using data envelopment analysis", Australian Journal of Agricultural and Resource Economics, Vol. 48, No. 2, pp. 347-369. ISSN 1467-8489. DOI 10.1111/j.1467-8489.2004.00243.x.

[20] Emrouznejad, A. and Yang, G. L. (2018) "A survey and analysis of the first 40 years of scholarly literature in DEA: 1978-2016”, Socioeconomic Planning Science, Vol. 61, pp. 4-8. ISSN 0038-0121. DOI 10.1016/j.seps.2017.01.008.

[21] Farrell, M. J. (1957) "The Measurement of Productive Efficiency", Journal of the Royal Statistical Society. Series A, Vol. 120, No. 3, pp. 253-290. ISSN 00359238. DOI 10.2307/2343100.

[22] FAO (2016) "Food and agriculture data". [Online]. Available: http://www.fao.org/faostat/en/\#home [Accessed: 25 July 2018].

[23] Galanopoulos, K., Aggelopoulos, S., Kamenidou, I. and Mattas, K. (2006) "Assessing the effects of managerial and production practices on the effciency of commercial pig farming", Agricultural Systems, Vol. 88, pp. 125-141. ISSN 0308-521X. DOI 10.1016/j.agsy.2005.03.002.

[24] Giametta, G. and Bernardi, B. (2010) "Olive grove equipment technology. Straddling trees: Mechanized olive harvests", Advances in Horticultural Science, Vol. 24, No. 1, pp. 64-70. ISSN 03946169.

[25] Gómez-Limón, J. A., Picazo-Tadeo, A. J. and Reig-Martínez, E. (2012) "Eco-efficiency assessment of olive farms in Andalusia", Land Use Policy, Vol. 29, No. 2, pp. 395-406. ISSN 0264-8377. DOI 10.1016/j.landusepol.2011.08.004. 
[26] Hosseinzadeh-Bandbafha, H., Safarzadeh, D., Ahmadi, E. and Nabavi-Pelesaraei, A. (2018) "Optimization of energy consumption of dairy farms using data envelopment analysis - A case study: Qazvin city of Iran", Journal of the Saudi Society of Agricultural Sciences, Vol. 17, No. 3, pp. 217-228. ISSN 1658-077X. DOI 10.1016/j.jssas.2016.04.006.

[27] Idda, L., Fusi, R., Madau, F. A., and Rubino, C. (2004) "L'olivicoltura in Sardegna. Aspetti economici e prospettive alla luce di un'analisi aziendale", Quaderni di Economia e Politica Agraria, No. 2., 102 p, Tipografia Gallizzi Editore. (In Italian).

[28] ISTAT (2010) " th $^{\text {th }}$ Italian agriculture census". [Online]. Available: http://dati-censimentoagricoltura. istat.it/. [Accessed: 10 July 2018].

[29] ISTAT (2016) “Agriculture and livestock”. [Online]. Available: http://agri.istat.it/sag_is_pdwout/ index.jsp. [Accessed: 10 July 2018].

[30] Jiao, W., Fu, Z., Mu, W., Zhang, X., Lu, J. and Xu, M. (2015) "Estimating technical efficiency of Chinese table grape wholesalers", British Food Journal, Vol. 117, No. 6, pp. 1670-1688. ISSN 0007-070X. DOI 10.1108/BFJ-03-2014-0134.

[31] Joro, T. and Korhonen, P. J. (2015) "Extension of Data Envelopment Analysis with Preference Information: Value Efficiency”, New York, Springer US, 191 p. ISBN 978-1-4899-7528-7.

[32] Jurado, E. B., Moral, A. M., Uclés, D. F. and Viruel, M. J. M. (2017) "Determining factors for economic efficiency in the organic olive oil sector", Sustainability, Vol. 9, No. 5, pp. 784. ISSN 2071-1050. DOI 10.3390/su9050784.

[33] Khoshroo, A., Mulwa, R., Emrouznejad, A. and Arabi, B. (2013) "A non-parametric Data Envelopment Analysis approach for improving energy efficiency of grape production", Energy, Vol. 63, pp. 189-194. ISSN 0360-5442. DOI 10.1016/j.energy.2013.09.021.

[34] Lansink, A. O. and Reinhard, S. (2004) "Investigating technical effciency and potential technological change in Dutch pig farming", Agricultural Systems, Vol. 79, pp. 353-367. ISSN 0308-521X. DOI 10.1016/S0308-521X(03)00091-X.

[35] Liu, J. S., Lu, L. Y. Y., Lu, W. M. and Lin, B. J. Y. (2013) “A survey of DEA applications”, Omega, Vol. 41, No. 5, pp. 893-902. ISSN 0305-0483. DOI 10.1016/j.omega.2012.11.004.

[36] Mardani, M. and Salarpour, M. (2015) "Measuring technical efficiency of potato production in Iran using robust data envelopment analysis", Information Processing in Agriculture, Vol. 2. No. 1, pp. 6-14. ISSN 2214-3173 DOI 10.1016/j.inpa.2015.01.002.

[37] Mohammadi, A., Rafiee, S., Mohtasebi, S. S., Mousavi Avval, S. H. and Rafiee, H. (2011) "Energy efficiency improvement and input cost saving in kiwifruit production using Data Envelopment Analysis approach", Renewable Energy, Vol. 36, No. 9, pp. 2573-2579. ISSN 0960-1481. DOI 10.1016/j.renene.2010.10.036.

[38] Mousavi-Avval, S.H., Mohammadi, A., Rafiee, S. and Tabatabaeefar, A. (2012) "Assessing the technical efficiency of energy use in different barberry production systems", Journal of Cleaner Production, Vol. 27, pp. 126-132. ISSN 0959-6526. DOI 10.1016/j.jclepro.2012.01.014.

[39] Niavis, S., Tamvakis, N., Manos, B. and Vlontzos, G. (2018) “Assessing and explaining the efficiency of extensive olive oil farmers: The case of Pelion peninsula in Greece", Agriculture, Vol 8, No 2, pp. 1-13. ISSN 2077-0472.

[40] Ramanathan, R. (2003) "An Introduction to Data Envelopment Analysis", New Delhi, Sage Publications, 208 p. ISBN 978-0761997610.

[41] Scardera, A. and Tosco, D. (2010) "Redditività delle aziende olivicole e impatto della riforma della PAC 2014-2020", Italy, INEA, p. 79. (In Italian).

[42] Sola-Guirado, R. R., Bernardi, B., Castro-García, S., Blanco-Roldán, G. L., Benalia, S., Fazari, A., Brescia, A. and Zimbalatti, G. (2018) "Assessment of aerial and underground vibration transmission in mechanically trunk shaken olive trees", Journal of Agricultural Engineering, Vol. 49, No. 3, pp. 191-197. ISSN 2239-6268. DOI 10.4081/jae.2018.788. 
[43] Stillitano, T., De Luca, A. I., Iofrida, N., Falcone, G., Spada, E. and Gulisano, G. (2017) "Economic Analysis of Olive Oil Production Systems in Southern Italy", Quality - Access to Success, Vol. 18, No. 157, pp. 107-112. ISSN 1582-2559.

[44] Stillitano, T., Falcone, G., De Luca, A.I., Spada, E., Gulisano, G. and Strano, A. (2018) "Long-term feasibility of Mediterranean olive production systems", Acta Horticulturae, Vol. 1199, pp. 203-208. ISSN 2406-6168. DOI 10.17660/ActaHortic.2018.1199.33.

[45] Theodoridis, A., Ragkos, A., Roustemis, D., Galanopoulos, K., Abas, Z. and Sinapis, E. (2012) "Assessing technical efficiency of Chios sheep farms with data envelopment analysis", Small Ruminant Research, Vol. 107, No. 2-3, pp. 85-91. ISSN 0921-4488. DOI 10.1016/j.smallrumres.2012.05.011.

[46] Toma, E., Dobre, C., Dona I. and Cofas, E. (2015) "DEA applicability in assessment of agriculture efficiency on areas with similar geographically patterns", Agriculture and Agriculture Science Procedia, Vol. 6, pp. 704-711. ISSN 2210-7843. DOI 10.1016/j.aaspro.2015.08.127.

[47] Urso A., Timpanaro G., Caracciolo F., Cembalo, L. (2018) "Efficiency analysis of Italian wine producers", Wine Economics and Policy, Vol. 7, No. 1, pp. 3-12. ISSN 2212-9774. DOI 10.1016/j.wep.2017.11.003.

[48] Vidal, F., Pastor, J. T., Borras, F. and Pastor, D. (2013) "Efficiency analysis of the designations of origin in the Spanish wine sector", Spanish Journal of Agricultural Research, Vol. 11, No. 2, pp. 294-304. ISSN 2171-9292. DOI 10.5424/sjar/2013112-3607. 